\title{
Effect of Reincarnation Beliefs on Work-Culture with reference Government \& Non-govt. Employed People
}

\author{
Mr. Manish Gupta ${ }^{1}$, Dr. Hemadri Sao ${ }^{2}$, Dr. Santosh Vishvakarma ${ }^{3}$
}

\section{ABSTRACT}

Work culture is blend of an attitude, ideology and principles of between an organization \& employees. Beliefs are the internal thinking set of mind and perceived in action and behavior. So, beliefs help in creation of work culture. In Indian culture and tradition Reincarnation beliefs one of the important phenomenon affected people. This research explores the effectiveness of Reincarnation Beliefs on work-culture on Government \& Non-government employed people. A Between groups comparative method \& design were carry out on the sample of 200 employed adult (50 government \& 50 non-government people who beliefs in reincarnation and 50 government \& 50 non-government people who do not beliefs in reincarnation) taken by Incidental sampling from Haridwar district and other nearest places. Self made questionnaire and check-list used for collection of data. Statistical analysis of data used "t-test." Data clearly indicated highly significant at 0.01 level of confidence thus indicating that, those who beliefs in reincarnation they have better work culture or attitude than who do not beliefs in reincarnation phenomenon.

Keywords: Reincarnation beliefs, Work-culture, Govt. \& Non-govt. employed.

All over the word, grooming of personality and behavior is the attraction point for betterment of life. In modern experimental psychology behavior is a main phenomenon or tool in measurement of personality and mind. Good behavior is essential elements required in human \& humanity development in a whole world. Behavior is the outer and action part of personality, but this action govern by our mind and our mind determine the way of action; but beliefs govern the mind; and Beliefs are the internal set of thinking. Pt. Sri Ram Sharma Acharya wrote many books for reforming thinking and gives scientific evidence and taught experiences for building "Positive beliefs" for the development of excellence individual and the society.

\footnotetext{
${ }^{1}$ Research scholar, Dept. of psychology, Dev Sanskriti Vishwavidyalaya, Haridwar (U.K.), India

${ }^{2}$ Professor \& Head, Dept. of psychology, Dev Sanskriti Vishwavidyalaya, Haridwar (U.K.), India

${ }^{3}$ Associate Professor, Dept. of Psychology, Dev Sanskriti Vishwavidyalaya, Haridwar (U.K.), India

(C) 2015 I M Gupta, H Sao, S Vishvakarma; licensee IJIP. This is an Open Access Research distributed under the terms of the Creative Commons Attribution License (http://creativecommons.org/licenses/by/2.0), which permits unrestricted use, distribution, and reproduction in any Medium, provided the original work is properly cited.
} 


\section{Effect of Reincarnation Beliefs on Work-Culture with reference Government \& Non-govt. Employed People}

A belief is a state of mind, indulgence in especially philosophy and psychology, as well as traditional culture, in which a subject roughly regards a thing to be true. Beliefs systems include both religions and philosophies that help to explain basic questions of human existence in the world. So beliefs are the root cause of behavior of individual. Overall beliefs are very important in every action of life, whether result is favorable or unfavorable to human existence. In religious and philosophy only beliefs are the strongest phenomenon in determining the basic structure of society. Beliefs of individual and beliefs of society can be differed and both can influenced each other. Beliefs play important role in the work culture of society by control of uncontrolled desire and behavior of human. Indian Beliefs are not only historical and traditional but also psychospiritual in nature, which directly impact on human tendency, work and behavior.

Reincarnation is the beliefs that a part of our consciousness will continue living after the death of the physical body and will be re-born into a new body here on Earth. The beliefs of reincarnation are widespread, in fact almost universal in the East, but it has never been that popular in the West. For many people the idea of life after death is very comforting because it reduces their grief and removes their fear of total destruction (Bladom, 2006).

The Reincarnation or Rebirth theory is directly related to the Karmfal theory. In the context of Indian psychology Reincarnation theory is based on Karmfal theory and Karmfal can be produced by only beliefs (Dwivedi,1969); so karmfal theory is some of an extent mixed with the reincarnation theory, because according to our Karma, soul enter in to the physical body. Our Karma produces fala. So bad or good karma both are the essential to endure for every kind of human. ShivPuran \& Mahabharat said- **vo";a fg d’ra deZ HkksDrO;a rf\}pk; ;Zrke**AA in other word- it is everyone essential to endure our karma (Sharma, S.R.1998).

Every moment of everyone life is affected by rules of Karmfal. If people followed or beliefs in this rules, does developed any psychological traits? And does develop any work attitude? Yes! Karmafal or Reincarnation is the combination of beliefs, values, attitude and behavior of people. Psychological traits and work attitudes are vital role-play in making personality of human behavior and society also. Traits \& attitude are related to mind, \& mind is the main element in human's life \& death. So mind is a basic element in beliefs of reincarnation theory, so beliefs of reincarnation can influence the personality and society as well. Western Psychologist F.W.Balis concluded that, "Man is not a body but consistent of a mind. This is a mind operating through a body. The body itself is the result of the activity of mind; it's module by mind and changed by mind" (Dwivedi, 1969).

Bhaskarananda, (2010) describe in his article that, the idea of reincarnation in Hinduism is perhaps as old as Hinduism itself. The idea of the transmigration of souls is also present in Hinduism. Generally speaking, a human soul evolves from incarnation to incarnation. Therefore, it is normal for a human soul to be born again and again only in human bodies until liberation. 


\section{Effect of Reincarnation Beliefs on Work-Culture with reference Government \& Non-govt. Employed People}

Bhaskarananda, (2010) describe about causes of Rebirth, when people die with strong unfulfilled desires, which can only be fulfilled on earth, their minds - while they are in the other world - strongly yearn for the fulfillment of those desires. As every conscious action is prompted by a thought, those unfulfilled desires eventually bring them back to earth, thus causing their rebirth or reincarnation.

Study by Waterhouse (2003) indicates, reincarnation beliefs are positively correlated with spirituality. A religious person has more chance for beliefs in reincarnation. Religious beliefs are also positive correlated with reincarnation beliefs. Reincarnation is a concept which is common to many religious beliefs and spiritual practices (Smith, 2003). In western literature, reincarnation beliefs are one of the parts of "Paranormal beliefs". While in Indian literature, the study of reincarnation beliefs is associated to religion

In some research study correlation of reincarnation beliefs with personality researcher find following result like; Lurene \& David (1995), explored whether beliefs in reincarnation was associated with the personality measure locus of control. Results indicate that an external locus of control was associated with beliefs in reincarnation but not with general beliefs in life after death. Somer, Sela, \& Or-Chen (2011), studied the influence of the beliefs in reincarnation and in the power of fate, as potential coping resources in the shadow of loss and bereavement. Burley (2013), Studied on reincarnation beliefs often assume that these beliefs are logically and historically prior to certain ethical values.

Persinger \& Fisher (1990), elevated and specific temporal lobe signs in a population engaged in psychic studies. This study done in 20 female members (aged 24-65 yrs) of a psychic group who reported frequent subjective psi experiences and endorsed exotic beliefs (e.g., beliefs in reincarnation) displayed significantly higher incidence of temporal lobe signs. Cooper, I.S. (1979) describe the chief purpose of reincarnation is education. To this end we are born again and again on earth, not because of any external pressure, but because we, as souls, desire to grow. The driving-power at the back of reincarnation, which brings us to earth again, is the thirst for experience, the desire for knowledge, the yearning to blend in the throb and rush of physical existence. Danelek, J.K., (2015), describe that Reincarnation is an idea that may seem strange, exotic, or even a little nonsensical to the western mind, but in fact it plays a vital role in understanding our purpose in the universe and why we spend time on this planet at all.

Stevenson, I. (1977) argues that, the idea of reincarnation may contribute to an improved understanding of such diverse matters as: Phobias and Philias (strong interest) of childhood; skills not learned in early life; abnormalities of child-parents relationship; vendettas and bellicose nationalism; childhood sexuality and gender identity confusion; birthmarks, congenital deformities and internal diseases; differences between members of monozygotic twin pairs; and abnormal appetites during pregnancy. In this article, Ian Stevenson wrote that, previous personality effect on above mention diverse matter. 


\section{Effect of Reincarnation Beliefs on Work-Culture with reference Government \& Non-govt. Employed People}

Work culture is a combination of qualities in an organization and its employees that arise from what is generally regarded as appropriate ways to think and act. (Lingham 2000). The "work culture" of an organization is a product of its history, traditions, values and vision. "a pattern of basic group assumptions that has worked well enough to be considered valid, and, therefore, is taught to new members as the correct way to perceive, think and feel.” (Lingham 2000). If work attitude or culture of a person is highly self motivated, it can be changed or influenced the culture of organization. It is also same in nature, if the work culture of any organization is strong, can be influenced work attitude of people also. The culture consist two elements that is Employed \& Organization. So, the culture of an organization known by its ideology \& principles; whereas employed known by their attitude or behavior.

The role of present study indicates the effect of beliefs in reincarnation on work culture or attitude or behavior is necessary elements to govern society ethically and morally.

\section{RESEARCH METHODOLOGY:}

\section{Variables:}

\section{Objective:}

- Independent Variable: $\quad$ Reincarnation beliefs

- Dependent Variable: Work culture

-Those people who beliefs in reincarnation phenomenon; are they have any leading work culture/attitude according to their profession?

-Those people who don't beliefs in reincarnation phenomenon; are they have any lack of work culture/attitude according to their profession?

Hypothesis: (Null Hypothesis - $\mathrm{H}_{\mathrm{O}}$ )

1-There is no significant difference in Work Culture of Govt. employed people who believe and who do not believe in Reincarnation phenomenon.

2-There is no significant difference in Work Culture of Non-govt. employed people who believe and who do not believe in Reincarnation phenomenon.

3- There is no significant difference in Work Culture between Government and Nongovt. employed people who believe in Reincarnation phenomenon.

4- There is no significant difference in Work Culture between Government and Nongovt. employed people who do not believes in Reincarnation phenomenon.

\section{Research design:}

A between groups comparative method is used. 


\section{Effect of Reincarnation Beliefs on Work-Culture with reference Government \& Non-govt. Employed People}

\section{Sample and Sampling:}

The selection of sample is based on used of Incidental sampling techniques. Subject divided into two groups that are those who believe and those who do not believe in reincarnation phenomenon. It has done on the basis of check list made for this purpose by researcher.

\section{Data collection:}

The entire subject selected mostly from Haridwar district and some from district of Utter Pradesh and few samples from other seven state of India. Data collection held with the help of Check list and Questionnaire developed by researcher.

\section{Inclusive \& Exclusion criteria:}

Few points are being mentioned below which are need to be considered as inclusion/exclusion criteria:

1. Only those subjects included who were adult and employed in Government and nongovernment organization.

2. Exclude those subjects who are unemployed and give improper response in filling of questionnaire and check list both.

\section{Tools used:}

Following material (scale) were used as a tools for the collection of data.-

1- A Check -List of Reincarnation Beliefs- (Developed by researcher) use of this check list is to find out two groups of people (sample) who believe and who do not believes in reincarnation phenomenon.

2- A Questionnaire of Work culture- (Developed by researcher) use of this questionnaire to find out; i- Work Attitude of people/sample, ii-ideology \& principle of their working organization.

\section{Procedure:}

Samples were selected from different state and district incidentally in camping or training session and other gathering of people in many occasions. All essential instruction was in written and verbally asks for any problem during filling questionnaire and check list. This check list helps us making two groups of people who believe and who do not believes in reincarnation phenomenon. After collection of data, scoring has been done according to response of sample in three point Lickert scale. 


\section{Statistical techniques:}

The raw data obtained by using respective tool used and further analysis computed with help of statistical techniques used t-test in ms office excel sheet.

\section{RESULT AND DISCUSSION:}

Finding Average Raw Score of “work culture questionnaire \& Check-list”, mentioned in Table-1

Table-1 (Average Raw Score)

\begin{tabular}{|l|l|l|l|}
\hline $\begin{array}{l}\text { Group } \\
\text { (50 sample each) }\end{array}$ & $\begin{array}{l}\text { Govt. employed } \\
(100 \text { sample })\end{array}$ & $\begin{array}{l}\text { Non-Govt. employed } \\
\text { (100 sample) }\end{array}$ \\
\hline A & who believes in reincarnation & 7835 & 7570 \\
\hline B & $\begin{array}{l}\text { who don't believe in } \\
\text { reincarnation }\end{array}$ & 6485 & 6261 \\
\hline
\end{tabular}

Plot-1(Average Raw Score)

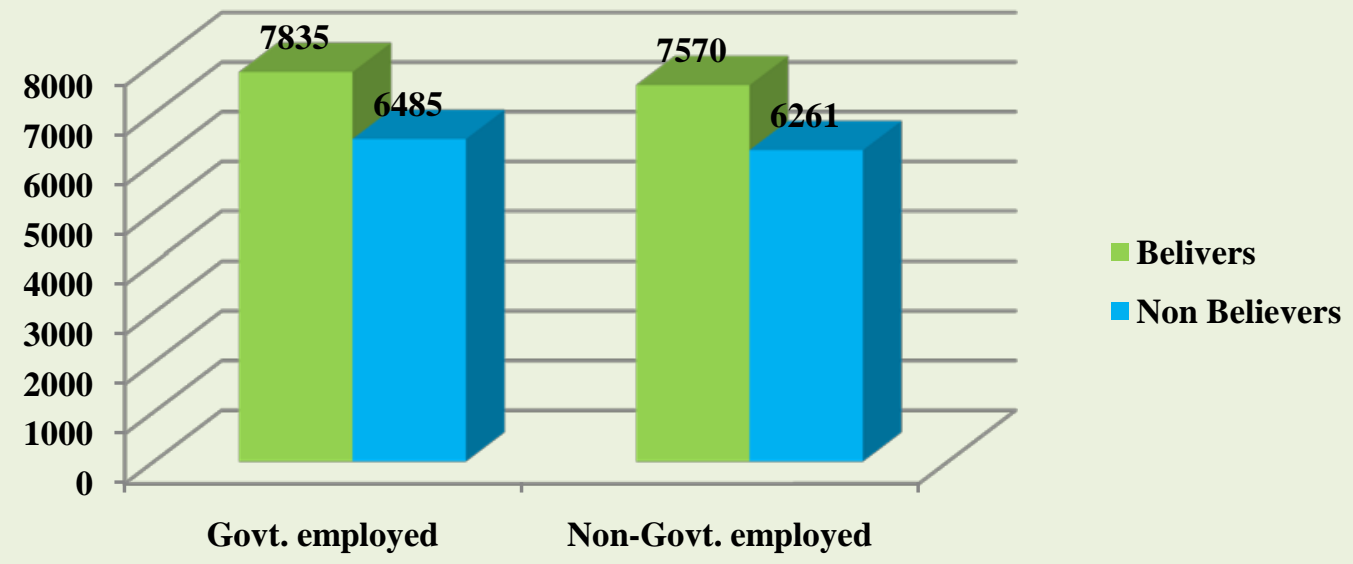

The first Hypothesis was undertaken in order to analyze that, there is no significant difference in work culture of believers and not believers in reincarnation phenomenon among government employed people. The testing of first hypothesis (Table-2) indicate and from t-table with $d f=98$ and $\alpha=0.01, t$ crit $=+2.617$ and Since $t_{\text {obt }}$ is $>2.617$ and we rejected $H_{0}$ and concluded that, there is significant difference in work culture of believers and not believers in reincarnation phenomenon among government employed people. 
Table 02 (Govt. employed)

\begin{tabular}{|l|l|l|l|l|l|l|l|}
\hline Group & $\mathbf{N}$ & Mean & SD & $\mathbf{S E}_{\mathbf{D}}$ & df & t-value & $\mathbf{P}$ \\
\hline $\begin{array}{l}\text { who believes in } \\
\text { reincarnation }\end{array}$ & 50 & 156.7 & & & & & \\
\cline { 1 - 3 } $\begin{array}{l}\text { who don’t believe } \\
\text { in reincarnation }\end{array}$ & 50 & 129.7 & 13.75 & 2.45 & 98 & 9.81 & $\mathbf{P}<0.01$ \\
\hline
\end{tabular}

Plot-1



The second study was undertaken in order to analyze that, there is no significant difference in work culture of believers and not believers in reincarnation phenomenon among Nongovernment employed people. The testing of second hypothesis (Table-3) indicate and from ttable with $d f=98$ and $\alpha=0.01, t$ crit $= \pm 2.617$ and Since $t_{\text {obt }}$ is $>2.617$ and we rejected $H_{0}$ and concluded that, there is significant difference in work culture of Non-govt. employed people who believe and who do not believe in Reincarnation phenomenon.

Table -3 (Non-Govt. employed)

\begin{tabular}{|l|l|l|l|l|l|l|l|}
\hline Group & $\mathbf{N}$ & Mean & SD & $\mathbf{S E}_{\mathbf{D}}$ & df & t-value & $\mathbf{P}$ \\
\hline $\begin{array}{l}\text { who believes in } \\
\text { reincarnation }\end{array}$ & 50 & 151.4 & & & & & \\
\cline { 1 - 3 } $\begin{array}{l}\text { who don’t believe } \\
\text { in reincarnation }\end{array}$ & 50 & 125.2 & 15.96 & 3.19 & 98 & 8.20 & $\mathrm{P}<0.01$ \\
\hline
\end{tabular}


Plot-2

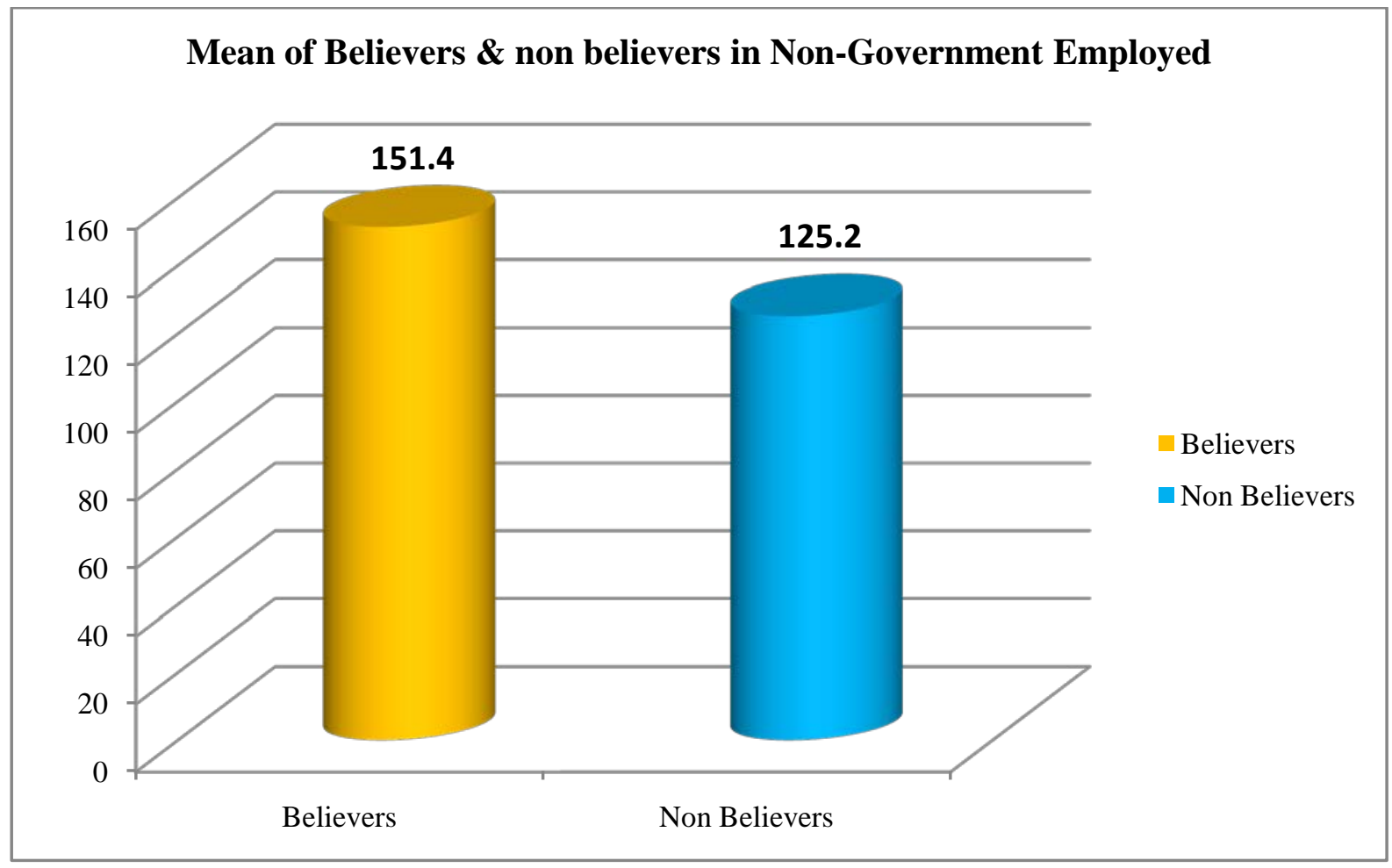

The third study was undertaken in order to analyze, there is no significant difference in Work Culture between Government and Non-govt. employed people who believe in Reincarnation phenomenon. Testing of third hypothesis (Table-4) indicate and from t-table with $d f=98$ and $\alpha=$ $0.05, t$ crit $= \pm 1.980$ and Since $t_{\mathrm{obt}}$ is $<1.980$ and we accepted $\mathrm{H}_{o}$; it means there is no significant difference in work culture between Government and Non-govt. employed people who believe in Reincarnation phenomenon.

Table 04 (Believers of Both groups)

\begin{tabular}{|c|c|c|c|c|c|c|c|}
\hline Group & $\mathbf{N}$ & Mean & SD & $S E_{D}$ & df & t-value & $\mathbf{P}$ \\
\hline $\begin{array}{l}\text { Government } \\
\text { Employed }\end{array}$ & 50 & 156.7 & \multirow[b]{2}{*}{13.43} & \multirow[b]{2}{*}{2.68} & \multirow[b]{2}{*}{98} & \multirow[b]{2}{*}{1.97} & \multirow[b]{2}{*}{$P>0.05$} \\
\hline $\begin{array}{l}\text { Non-govt. } \\
\text { Employed }\end{array}$ & 50 & 151.4 & & & & & \\
\hline
\end{tabular}




\section{Effect of Reincarnation Beliefs on Work-Culture with reference Government \& Non-govt. Employed People}

The fourth study was undertaken in order to analyze there is no significant difference in Work Culture between Government and Non-govt. employed people who do not believes in Reincarnation phenomenon. Testing of fourth hypothesis (Table-5) indicate and from t-table with $d f=98$ and $\alpha=0.05, t$ crit $= \pm 1.980$ and Since $t_{\text {obt }}$ is $<1.980$ and we accepted $\mathrm{H}_{o}$; it means there is no significant difference in Work Culture between Government and Non-govt. employed people who do not believes in Reincarnation phenomenon.

Table 05 (Not believers of both groups)

\begin{tabular}{|c|c|c|c|c|c|c|c|}
\hline Group & $\mathbf{N}$ & Mean & SD & $\mathrm{SE}_{\mathrm{D}}$ & df & t-value & $\mathbf{P}$ \\
\hline $\begin{array}{l}\text { Government } \\
\text { Employed }\end{array}$ & 50 & 129.7 & & 221 & Q० & 120 & D) $>0$. \\
\hline $\begin{array}{l}\text { Non-govt. } \\
\text { Employed }\end{array}$ & 50 & 125.2 & 16.22 & 3.24 & 98 & 1.38 & $P>0.05$ \\
\hline
\end{tabular}

The above cited results (table-2, hypothesis-1) reveals highly significant differences on 0.01 level, so there is highly significant difference in Work Culture of Govt. employed people who believe and who do not believe in Reincarnation phenomenon. The next cited results (table3,hypothesis-2) reveals highly significant differences on 0.01 level; so there is highly significant difference in Work Culture of Non-Govt. employed people who believe and who do not believe in Reincarnation phenomenon. Whereas, third hypothesis (Table-4) and fourth hypothesis (Table-5) reveals do not significant even at 0.05 level of significant level.

\section{DISCUSSION:}

Result indicated positively correlation in between reincarnation beliefs and attitude or work culture among both types of people, weather government employed people or non- government employed people (Table-2 \&3). Data indicated that, Believers in reincarnation scored high on work culture and at the opposite Not believers in reincarnation scored low on work culture (Table-1).

But according (Table-4) there is no significant differences seen in believers \& non-believers on both group of employed people in their work culture (Table-5). It means both types of employed people (private or government) have nearly same attitude or work culture, but mean of both groups are low differences seen, but not in significant level.

Basically every person is social in nature, when people do any activity for survival they bind with social norms, traditions and customs. These are important for integrated development of humanity. But many people feel these are problematic in their freedom of life, they do not beliefs in such things and avoid it. The desire of freedom of life, indicate the selfish or detached with the society. So the activity and behavior become self oriented. That does impact on attitude and 


\section{Effect of Reincarnation Beliefs on Work-Culture with reference Government \& Non-govt. Employed People}

nature of personality, traits or behavior etc. In the same way ideology and principles of the organization determine the work culture. While beliefs determine the ideology and principle; so beliefs are the strongest mental set in determining work culture of people and organization both.

Mean of believers in reincarnation is higher than Non believer's people (see fig. Plot-1 \& Plot2). It indicated that believers in reincarnation phenomenon and their work culture are higher than non-believer's people. The reason behind can be said that, the life is so easeful and relax for believers than non-believers. So believers may most satisfy in their work, instead of nonbelievers. Non-believers are more self-oriented and less time for their customs, value and culture even for self and their family, so it is very difficult to manage their life and work attitude according to Indian tradition and culture. So non-believers have poor work culture than believers. This concept can be considered for both types of employed people.

Reincarnation phenomenon is closely related with Karmafal theory. Reincarnation is the result of Karma. Karma determines the nature of reincarnation. In the same way people who do not beliefs in reincarnation phenomenon, they achieve low score and they have generally lower work culture and attitude, and so they have poor work culture than who beliefs in reincarnation. People of poor work culture means they have some lacking in traits of personality like; excellence in work, lower adjustment level, less liberal, problem creator, low self confident, poor relationship, time mismanagement, emotionally imbalanced, poor self concept, pessimistic etc.

\section{CONCLUSION}

The research concluded that, "Non-believers in reincarnation phenomenon having poor work culture than Believers of reincarnation phenomenon. Reincarnation is a life-death cycle describes by Jyotirmay (2015), that, death is not the end of life, but it is an encampment or stage. Life also runs after death in some different manner. In a survey of worldwide agency (The innovation of and branch research specialists-IPSOS) find that, "beliefs in continuous of life gives energy to the people and life grow better." these beliefs able to tolerate energy of problems of people. Beliefs in reincarnation people get opportunity for better spiritual and peaceful life and ultimately their attitude and work culture is better. In this study the researcher find thinking pattern and attitude or behavior of people is significant different among believers and non believers in reincarnation phenomenon.

\section{REFERENCES}

Bhaskarananda, S. (2010). Concept of reincarnation, The Vedanta Society of Western Washington, from http://www.vedanta-seattle.org/articles/hindu-concept-ofreincarnation.

Bladom, L. (2006). Reincarnation and its psychological effect on children, Retrieved ( 2013, nov.) from http://www.ukessays.com/essays/psychology/reincarnation- and-itspsychological-effect-on-children-psychology-essay.php. 


\section{Effect of Reincarnation Beliefs on Work-Culture with reference Government \& Non-govt. Employed People}

Burley, M. (2013). Reincarnation and ethics. Journal of the American Academy of Religion, 81, (1) 162 - 187. ISSN 0002-7189.

Cooper, I.S. (1979). Reincarnation, a hope of the world, The Theosophical Publishing House from https://www.theosophical.org /files /resources/ books/ Reincarnation / Reincarnation.pdf.

Danelek, J.K., (2015). The Purpose and Function of Reincarnation, the Llewellyn journal, from http://lewellyn.com/journalarticle_topic.php?article topic=paranormal

Dwivedi, G. S. (1969). Perlok \& Punerjanmank, Gorakhpur, Geeta press.

Garret, H.E. \& Woodworth, R.S.(1981). Statistics in psychology \& education, Mumbai, Vakils Feffer and Simons ltd.

Jyotirmay (2015, may 29). Ab kafi nahi ek hi bhagvan, Sradhha, 18, AmarUjala Hindi newspaper, Dehradun ed.

Lingham, Leo (2000). Introduction of work culture, Article from http://www.citehr.com/23671work-culture-introduction-book.html

Lurene A. \& David, L.(1995). Psychological-Reports; 76(3, Pt 1) 1018.

Persinger,M.A. \& Fisher, S. D.(1990), Perceptual-and-Motor-Skills; 71(3, Pt1) 817-818.

Sharma S.R.,(1998). Marnottar jeevan tathya evam satya, Mathura, Akhand Jyoti sansthan,

Smith,S.E.(2003). Reincarnation and its psychological effect on children, Retrieved November 8, 2013 from http://www.ukessays.com/essays/psychology/

Somer, E., Sela, C.K. \& Or Chen, K. (2011). Journal of Loss and Trauma: International Perspectives on Stress \& Coping 16(5), 459-475.

Stevenson, I.(1992). Birthmarks and birth defects corresponding to wounds on deceased persons. Presented at the eleventh annual meeting of the society for scientific exploration held at Princeton University. (June 11-13, 1992).

Waterhouse, H. and Walter, T. (2003). Reincarnation beliefs and the Christian churches. Open research online journal article, $u . k$. from http:// www. spck.org.uk/ cat/ theology.php 